\title{
JOACHIM MARTINS OF GHENT AND HIS TRANSLATION OF GALEN'S DIET BOOK
}

\section{ELAUT}

GALEN was among the very first medical authors of antiquity to stir the interest of the Renaissance humanists. His Opera Omnia, edited by Diomedes Bonardo of Brescia and printed by Fillippo Pinzio, appeared at Venice in 1490. The first issue of his work in the original Greek was by Aldus Manutius at Venice in 1525 . Another Greek edition was brought out at Basle in $153^{8}$ by Andreas Cratander. The most important impetus to the study of Galen was provided by the five-volume Aldine edition of 1525 .

The writings left behind by Galen are very extensive and cover every aspect of medicine. In 1526 no less a scholar than Erasmus published a translation of three minor Galenic treatises in honour of his doctor, John Antonius, who had taken care of him at Basle in the spring of 1524 and had just received the appointment of Physician in Ordinary to the Hungarian Court. ${ }^{1}$

Galen had many admirers among those who gathered round Erasmus. Among the new humanists it was a fashionable pursuit to make exhaustive studies of Galen, to compare the Latin translations of his works with the original texts, and to discuss the value of his philosophical system.

Among those who took up the study of the medical writings of antiquity was the physician Joachim Martins (Joachimus Martinius), a native of Ghent. Biographical data concerning this man are very meagre, but he is represented as an authority on Galen and is said to have published two books of the Greek physician and to have edited his complete works. ${ }^{2}$

There does not appear to be any reliable evidence of Martins having edited the Opera Omnia of Galen and it is difficult to see why he should have been credited with such a work. It is very significant that no bibliographer or authority on Galen mentions an edition of the complete works published or edited by Martins. G. G. Kühn in the exhaustive study prefixed to his monumental edition of Galen makes no mention of Martins and he was apparently unaware of the existence of the edition of De Alimentorum Facultatibus which forms the subject of this note. ${ }^{3}$ Neither Sarton ${ }^{4}$ nor Castiglioni ${ }^{5}$ make any reference to an edition of Galen prepared by Martins. There is no record of a Galen edited by Martins in the printed catalogues of the British Museum or the Bibliothèque Nationale.

We do not intend to pursue the question of whether Martins did or did not bring out a complete Galen any further, because the purpose of this note is to examine a Galenic work which certainly was brought out by the physician of 


\section{Elaut}

Ghent. Apart from the Latin text in the Aldine volumes it was the first translation into Latin of the Galenic treatise and its precision and distinguished style make it an outstanding example of humanistic scholarship. The dates of Martins' birth and death are uncertain; we only know that he returned to his native Ghent after the death of Erasmus in 1536 .
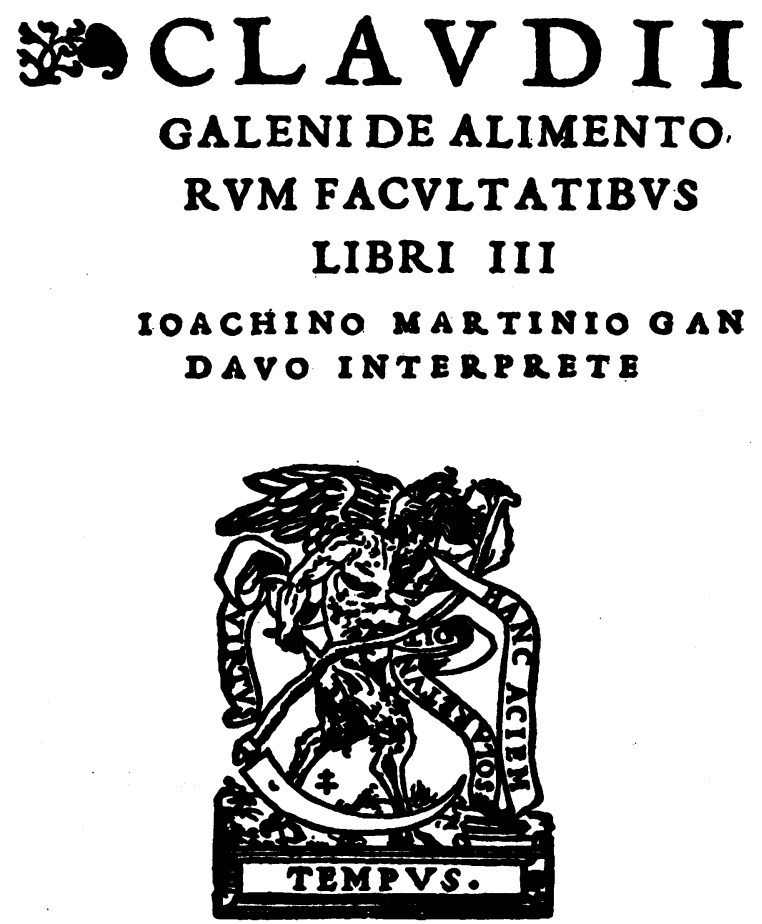

PARISIIS

APVD SIMONEM COLINAEVM

I $3 \circ$

Fig. I. Title-page of Joachim Martins' translation of Galen's Diet Book

The title of Martins' book runs as follows: CLAVDII / GALENI DE ALIMENTO / RVM FACVLTATIBVS / LIBRI III, Ioachino Martinio Gan / davo Interprete. The centre of the title-page is taken up by the device of Simon Colinaeus, the printer (see fig. I). The university library at Ghent possess a vellum-bound copy measuring 20.5 by $10.5 \mathrm{~cm}$. (No. $\mathrm{G}_{7892}$ ).

In his foreword to the reader Martins explains that he has been struck by the numerous mistakes which mar the Aldine text: 'multis in locis graecus Galeni codex, qui ex Asulani officina prodiit, mutilus ac depravatus'. As this work might be expected to shed special light upon Galen's scientific activity Martins felt it incumbent upon him to free it from all errors and I 58 


\section{Foachim Martins of Ghent and His Translation of Galen's Diet Book}

blemishes. The Latin Aldine edition was full of such corruptions and as an ardent follower of Erasmian principles he felt compelled to maintain the high critical and literary standards set up by the Prince of Humanists. Contrary to the custom adopted by most of his contemporaries, Martins did not include a dedicatory letter in his book. A brief dedication is, however, included in the title of his first book: Liber I Ioachino Martinio Gandavo, interprete ad Iacobum Sadoletum Carpentoracten Episcopum. This James Sadoleto was another outstanding humanist who had come into touch with the circle of Erasmus. He was a native of Modena, and a pupil of Nicolas Leoniceno of Ferrara, a scholar who had translated and criticized some of Galen's writings. Sadoleto was a most distinguished churchman and his Latin was said to be as refined as that of Cicero himself. Concerning his commentaries on the Psalms and on the Epistles of St. Paul, Erasmus passes the curious criticism, 'that their very high polish of expression will with some take off the edge of their pious suggestions'. ${ }^{6}$ Martins' dedication to such a man provides valuable evidence of the liberal spirit that prevailed among churchmen who attached considerable importance to Galen and his philosophical system.

Martins found an ideal printer in Simon Colinaeus, who seems to have specialized in the production of Galen's works. Between 1528 and 1532 he issued at least seven editions of Galen from his Paris press and these included the commentaries of Leonicino of Ferrara and Linacre of England.

It was of course the general interest in the subject-matter of Galen's De Alimentorum Facultatibus which led to its being chosen as one of the first works to be published in a separate translation. The subject of food and diet appealed to the professional man and no less to the lay person who wished to look after his own nutrition and health; the latter would find all that he needed in a book not over-charged with technical details which would be understood only by physicians. This was the period of the amateur even in matters of medicine, and the book therefore soon became the guide of every learned person who thought that he ought to keep to a diet.

Galen's manual of nutrition outclassed all the other diet books that came down from Greece or Rome, even those of Hippocrates. The majority of these works were fragmentary or restricted in their scope, but Galen provided a general and comprehensive survey of the whole subject. Subsequent authors, dieticians and hygienists borrowed freely and extensively from Galen: few books have been so frequently plagiarized. With the modern emphasis on the importance of dietetics for the maintenance of individual and public health, interest in Galen's diet book has not decreased. The prefaces to text-books of nutrition contain many references to Galen and his opinions and quotations from $D e$ Alimentorum Facultatibus are commonly given under chapter headings. The work is a great stand-by for young German doctors seeking a subject for their graduation thesis. From 1937 to 1940 the University of Munich registered no less than eleven dissertations on Galen's book.

De Alimentorum Facultatibus is divided into three books. The first deals with the starchy products of nature and the foods that can be prepared from them; 


\section{Elaut}

the second is concerned with fruits and vegetables; and the third treats of foods of animal origin. Galen does not merely list all foods and drinks; he deals with the preparation of foods, with the palatability and digestibility of various dishes, their nutritional qualities, and directions for their choice and use both in health and sickness. The book contains a thoroughly scientific treatment of nutritional teaching up to the time of Galen, enriched by his long experience and illuminated by the perspicuousness of his genial mind.

The Latin translation of Martins was an unmistakable fruit of the Erasmian orchard, but it was not over-refined and polished. Many readers would prefer it to the style of Erasmus himself, who is sometimes too laboured.

Apart from this book practically nothing is known of Joachim Martins' personality and work, but he deserves to be remembered as one of the many medical humanists of the Renaissance.

\section{REFERENCES}

1. Galeni Medicorum Principis Exhortatio ad bonas arteis, etc. Basle, Froben, 1526.

2. Biographie Nationale Belge, Brussels, 1895, 13, 908.

3. Galen. Opera Omnia. Ed. curavit C. G. Kühn. 22 vols. Leipzig, Cnobloch, 1821-33.

4. SART ON, G., Introduction to the History of Science, Baltimore, 1927.

5. Castiglioni, A., History of Medicine, London, 1947.

6. British Universities Encyclopaedia, 9, 7. 